\title{
PATEN SEBAGAI RISET PENDUKUNG YANG RELEVAN DALAM REVOLUSI INDUSTRI 4.0
}

\author{
Arga Ade Audiya \\ 175100064P, 785567881 \\ Fakultas Komputer \\ argaadeaudiya.student@umitra.ac.id
}

\begin{abstract}
Kemajuan teknologi dalam revolusi industri generasi ke-4 ini mengalami terobosan luar biasa. Untuk dapat bersaing dalam era revolusi industri generasi ke-4 ini kita perlu meningkatkan kemampuan bangsa dalam mengembangkan keunggulan teknologi yang kompetitif dan mengembangkan kreatifitas yang berbasis pada kekayaan intelektual khusus paten. Pengembangan sistem paten di Indonesia tidaklah semata-mata karena tekanan dunia internasional, namun juga karena kebutuhan nasional untuk menciptakan suatu sistem perlindungan paten yang efektif dan juga bermanfaat bagi bangsa Indonesia. Perangkat hukum di bidang paten diperlukan untuk memberikan perlindungan hukum dan mewujudkan suatu iklim yang lebih baik bagi kegiatan invensi teknologi serta mempermudah masuknya teknologi ke dalam negeri. Untuk memperlancar tujuan itu semua maka perlu di dilakukan pembaharuan sistem paten diantaranya: ketentuan pengungkapan yang cukup (sufficient disclosure), ketentuan pengecualian terhadap hak eksklusif paten, ketentuan lisensi paten, ketentuan lisensi wajib paten, dan sistem pelayanan informasi paten.
\end{abstract}

Kata kunci: paten, invensi, teknologi, hak eksklusif, lisensi wajib 


\section{A. INTRODUCTION}

Revolusi industri generasi ke-4 ini memiliki skala, ruang lingkup dan kompleksitas yang luas. Kemajuan teknologi baru yang mengintegrasikan dunia fisik, digital dan biologis telah mempengaruhi semua disiplin ilmu, ekonomi, industri dan pemerintah. Bidang-bidang yang mengalami terobosoan berkat kemajuan teknologi baru diantaranya :

(1) robot kecerdasan buatan (artificial intelligence robotic),

(2) teknologi nano,

(3) bioteknologi, dan

(4)teknologi

komputer kuantum,

(5) blockchain (seperti bitcoin),

(6) teknologi berbasis internet, dan

(7) printer 3D.

Sebagai dampak dari revolusi industri generasi ke-4 ini, Indonesia dihadapkan pada suatu tantangan yaitu adanya persaingan yang semakin tajam. Untuk dapat bersaing dalam era perdagangan bebas kita perlu meningkatkan kemampuan bangsa dalam mengembangkan keunggulan teknologi yang berbasis paten (Jened, 2000). Tingkat penguasaan teknologi oleh suatu negara akan menentukan apakah negara itu termasuk kategori negara maju atau negara berkembang, sebab negara yang memiliki teknologi maju akan bermuara pada bidang-bidang lain seperti penguasaan ekonomi (Kesowo, 1994). Dengan memperhatikan arti dan peran teknologi yang begitu penting dalam industri, maka tidaklah mungkin pencapaian sasaran pembangunan industri nasional dapat dilakukan dengan mengabaikan teknologi. Oleh sebab itu, negara perlu memberikan perlindungan hukum terhadap invensi tersebut, yang dapat menciptakan iklim yang baik dan mampu mendorong gairah atau semangat inventor menghasilkan invensi teknologi. Setidaknya, iklim yang lebih memungkinkan bangsa Indonesia untuk mengembangkan dan meningkatkan kemampuan dalam menguasai teknologi. Teknologi pada dasarnya lahir dari karsa intelektual, sebagai karya intelektual manusia. Adanya kepastian bahwa hak seseorang akan memperoleh perlindungan hukum itulah, yang pada gilirannya akan memperkuat iklim yang baik bagi penyelenggaraan kegiatan yang melahirkan teknologi. Dalam ilmu hukum disebut perlindungan paten, sebagai hak atas invensi tersebut. Paten adalah hak yang khusus (eksklusif) sifatnya, hak paten memberikan hak monopoli secara terbatas. Artinya, hak yang hanya diberikan kepada pemegangnya untuk dalam jangka waktu tertentu melaksanakan sendiri invensi tersebut, atau untuk memberi 
kewenangan kepada orang lain guna melaksanakannya. Dalam waktu tertentu itu pula, pihak lain dilarang untuk melaksanakan invensi tersebut kecuali atas ijin pemegang paten yang bersangkutan. Undang-Undang Paten pertama di Indonesia, yakni UU No. 6/1989, yang berlaku efektif tanggal 1 Agustus 1991. Setelah Indonesia meratifikasi Perjanjian tentang AspekAspek Hak Kekayaan Intelektual yang Terkait Perdagangan (Trade Related Aspects of Intellectual Property Rights untuk selanjutnya disingkat TRIPs), UU ini kemudian direvisi dengan Undang-Undang No. 13/1997. UU No. 6/1989 mengalami perubahan yang menyeluruh, yakni dengan disahkan Undang-Undang No. 14/2001, yang mulai berlaku sejak tanggal 1 Agustus 2001. Perubahan menyeluruh ini, selain dimaksudkan untuk menyesuaikan dengan perkembangan teknologi yang sedemikian pesat dan makin tinggi kesadaran masyarakat untuk meningkatkan pendayagunaan teknologi yang sederhana, juga dimaksudkan untuk menampung beberapa aspek atau ketentuan dalam TRIPs yang belum ditampung dalam UU No. 6/1989. Pada bulan Agustus 2016 kemarin UU No. 14/2001 diganti dengan Undang-Undang Nomor 13/2016, karena UU No. 14/2001 dianggap tidak sesuai dengan perkembangan hukum, baik nasional maupun internasional. Indonesia sebagai anggota Organisasi Perdagangan Dunia (World Trade Organization atau WTO) yang juga meratifikasi TRIPs tidak hanya perlu patuh terhadap peraturan-peraturan tersebut tetapi juga memiliki kewajiban melindungi rakyatnya khususnya dibidang kesehatan publik. Hak individu yang diberikan kepada inventor atau pemegang paten sebagaimana diatur dalam Undang - undang Paten, seharusnya juga tetap dapat memberikan kemaslahatan bagi masyarakat.

Dalam mengembangkan sistem paten di Indonesia tidaklah sematamata karena tekanan dunia internasional, namun juga karena kebutuhan nasional untuk menciptakan suatu sistem perlindungan HAKI yang efektif dan juga bermanfaat bagi masyarakat.

\section{B. CONTENT}

Pada tulisan kali ini makan membahas mengenai ketentuan-ketentuan apa saja dalam UU Paten No. 13/2016 yang perlu dilakukan pembaharuan agar lebih memberi manfaat kepada bangsa Indonesia?

1. PEMBAHARUAN SISTEM PATEN NASIONAL

Ada beberapa ketentuan dalam UU No. 13/2016 yang perlu 
kita kritisi dalam pembaharuan sistem paten Nasional, diantaranya: ketentuan pengungkapan yang cukup (sufficient disclosure), ketentuan pengecualian terhadap hak eksklusif paten, ketentuan lisensi paten, ketentuan lisensi wajib, dan sistem pelayanan informasi paten.

(1) Pengungkapan yang Cukup (Sufficient Disclosure) Ketentuan pengungkapan yang cukup dalam TRIPs diatur dalam Article 29

(1). Peter Mahmud Marzuki menyatakan bahwa salah satu prinsip yang penting dalam hukum paten adalah prinsip keterbukaan (disclosure) (Marzuki, 1993), bisa juga dirujuk pada (Jened, 2000). Prinsip ini mewajibkan pemohon paten untuk mengungkapkan secara jelas dan lengkap invensi yang dimintakan perlindungan agar invensi tersebut dapat dilakukan oleh seorang yang memiliki keahlian biasa dibidang teknik penemuan pada saat pendaftaran paten. Menurut Li Westerlund seperti yang dikutip oleh Peter Mahmud Marzuki, pengungkapan secara memadai (sufficient disclosure) ini berfungi (Marzuki, 1993):

1. Mengidentifikasikan invensi yang berguna sebagai informasi kepada pihak ketiga tentang isi Paten;

2. Mengidentifikasikan ruang lingkup perlindungan Paten sehingga pengadilan dapat membuat putusan secara benar atas kasus pelanggaran paten, utamanya jika menerapkan prinsip doctrine of equivalence;

3. memberikan informasi dan pembelajaran pada saat permohonan pendaftaran Paten yang dimaksudkan untuk peningkatan pengetahuan masyarakat. Dari pendapat $\mathrm{Li}$ Westerlund diatas sudah jelas bahwa ketentuan ini disamping ditujukan untuk kepentingan inventor juga untuk kepentingan masyarakat. Di sisi inventor, dengan adanya kejelasan pengungkapan invensi adalah untuk menentukan batas-batas perlindungan atas invensi yang bersangkutan. Di sisi lain dengan pengungkapkan invensinya secara cukup, jelas dan lengkap memberikan manfaat kepada masyarakat berupa kesempatan untuk melakukan modifikasi atau sebagai motivasi sehingga terjadi pengembangan atas invensi yang sudah ada atau lahir invensi baru. Melalui pengungkapan yang cukup akan memberikan pengembangan teknologi untuk kemanfaatan masyarakat luas dan dengan terpenuhinya syarat pengungkapan maka Negara akan memberikan perlindungan yang layak terhadap invensi (Jened, 2000). Bahwa setiap inventor yang mendaftarkan paten asalkan invensinya memenuhi persyaratan paten (patentability) dan mau melakukan pengungkapan yang cukup jelas dan lengkap terhadap invensinya, maka akan memdapat 
perlindungan paten. Tidak ada perlakuan yang beda terhadap warga negara dari negara anggota lainnya dengan Warga Negaranya. Dalam system paten di Indonesia tidak ada aturan secara eksplisit yang mengatur syarat pengungkapan yang cukup (sufficient disclosure) saat permohonan pendaftaran paten (Jened, 2000). Seharusnya Undang-undang Paten kita (UU No. 13/2016) memasukkan syarat pengungkapan yang cukup secara jelas sehingga sistem paten secara nyata dapat memberikan kontribusi yang besar terhadap perkembangan teknologi di Indonesia. (2) Pengecualian terhadap Hak Eksklusif Paten Ketentuan pengecualian hak eksklusif paten diatur dalam pasal 19 ayat (3) UU Paten No. 13/2016. Bahwa sistem paten selain ditujukan untuk kepentingaan pemegang paten, juga memberi manfaat untuk masyarakat. Setelah inventor menerima paten ia mempunyai hak eksklusif untuk menerapkan patennya itu. Hak eksklusif dalam penjelasan pasal 19 ayat (1) artinya hak yang hanya diberikan kepada pemegang paten untuk jangka waktu tertentu guna melaksanakan sendiri secara komersial atau memberikan hak lebih lanjut untuk itu kepada orang lain. Tetapi untuk pihak yang betul-betul memerlukan penggunaan invensi semata-mata untuk kepentingan pendidikan, penelitian, percobaan, atau analisis, dapat menggunakan invensi tersebut tanpa persetujuan dari pemegang paten. Ketentuan ini menunjukkan bahwa ketentuan pengecualian hak eksklusif paten ini bermanfaat untuk kepentingan masyarakat. Disamping itu, yang dimaksud dengan untuk kepentingan pendidikan, penelitian, percobaan, atau analisis, mencakup juga kegiatan untuk keperluan uji bioekivalensi atau bentuk pengujian lainnya (Saidin, 2003). Ketentuan pengecualian hak eksklusif paten, berupa pemakaian paten untuk kepentingan pendidikan, penelitian, percobaan, atau analisis tanpa persetujuan dari pemegang paten ini juga harus berlangsung atas dasar ketentuan yang adil. Ketentuan pengecualian hak eksklusif paten, berupa pemakaian paten untuk kepentingan pendidikan, penelitian, percobaan, atau analisis berlangsung atas dasar ketentuan yang adil, ditunjukkan dengan adanya ketentuan: bahwa pemakaian paten untuk kepentingan pendidikan, penelitian, percobaan, atau analisis tanpa persetujuan pemegang paten boleh dilakukan sepanjang tidak merugikan kepentingan yang wajar dari Pemegang Paten dan tidak bersifat komersial. Istilah "sepanjang tidak merugikan kepentingan yang wajar dari Pemegang Paten" dimaksudkan agar pelaksanaan atau penggunaan invensi tersebut tidak digunakan untuk kepentingan yang mengarah kepada eksploitasi untuk kepentingan komersial sehingga dapat merugikan, bahkan dapat menjadi kompetiter bagi pemegang paten. Agak sulit memang memberi batasan tentang tidak merugikan untuk kepentingan 
komersial. Delik terhadap pelanggaran paten termasuk dalam delik aduan. Semakin sulit pemegang paten untuk mengajukan tuntutan pidana, karena pengadu harus yakin terlebih dahulu bahwa hal itu benar-benar merugikan kepentingan yang wajar (Saidin, 2003).

Sehingga perlu diberi kriteria yang jelas ketentuan "sepanjang tidak merugikan kepentingan yang wajar dari Pemegang Paten" yang diatur pasal 19 ayat (3) UU No. 13/2016 sehingga ketentuan pembatasan hak eksklusif paten berupa pemakaian paten untuk kepentingan pendidikan, penelitian, percobaan, atau analisis berlangsung atas dasar ketentuan yang adil. (3) Perjanjian Lisensi Paten Di Indonesia perjanjian lisensi paten diatur dalam UU Paten No. 13/2016 dalam pasal 76 sampai dengan 107. Beberapa pembatasn dan larangan dalam perjanjian lisensi paten telah dicantumkan dalam pasal 78 UU Paten No. 13/2016. Dari pasal 78 dapat dilihat dua macam larangan dalam perjanjian lisensi paten (Saidin, 2003). a. Perjanjian lisensi tidak boleh memuat ketentuan yang dapat merugikan kepentingan nasional Indonesia. b. Perjanjian lisensi tidak boleh memuat pembatasan yang menghambat kemampuan bangsa Indonesia dalam melakukan pengalihan, penguasaan, dan pengembangan tenologi. Dalam penjelasan pasal 78 dinyatakan, yang dimaksud dengan "kepentingan nasional" adalah suatu hal atau tindakan ideologi, politik, ekonomi, sosial dan budaya, pertahanan dan keamanan, kepentingan energi, teknologi dan kepentingan lain untuk mencapai tujuan nasional bangsa Indonesia sebagaimana tercantum dalam Undang-Undang Dasar Negara Republik Indonesia Tahun 1945. Sedangkan pembatasan yang menghambat kemampuan bangsa Indonesia dalam melakukan pengalihan, penguasaan, dan pengembangan tenologi tidak dijelaskan. Sebenarnya ketentuan yang kedua dari pasal ini perlu penjelasan mengenai apa yang dimaksud. Dengan memperhatikan ketentuan diatas maka ruang lingkup dan pengertian ketentuanketentuan atau pembatasan-pembatasan ketentuan dalam perjanjian lisensi paten kurang jelas. Pembatasanpembatasan dalam perjanjian lisensi yang bagaimanakah yang diizinkan dan bagaimanakah yang dilarang. Misalnya, bolehkah para pihak dalam perjanjian lisensi paten membuat pasal-pasal pengikat (tie-in clause), clausula pemberian kembali (grant-back clause), lisensi paket dan lain-lain. Oleh karenanya, bila para pihak memasukkan klausula-klausula ini, ada kemungkinan dimasukkannya kendala, hambatan atau rintangan terhadap penerima lisensi. Dengan demikian, pemerintah harus menjelaskan dan memberi kepastian mengenai ruang lingkup dan pengertian dari pasal ini. Tanpa penjelasan atas pasal ini, kedudukan penerima lisensi dalam negeri akan tetap lemah dan akan 
merugikan perkembangan ekonomi dan teknologi di Indonesia. Berdasarkan pasal 76 ayat (3) UU Paten No. 13/2016, tentang jangka waktu lisensi paten maka pemilik paten atau pemberi lisensi memungkinkan membuat perjanjian lisensi paten melebihi jangka waktu hak paten, hal ini sangat merugikan penerima paten. Sehingga perlu dilakukan perubahan terhadap pasal 76 ayat (3) tersebut dengan menetapkan jangka waktu perjanjian lisensi paten, maksimal selama batas waktu paten, sehingga bila peten tersebut sudah menjadi milik umum, royalti tidak perlu dibayarkan lagi. (4) Lisensi Wajib Paten Dalam UU Paten No. 13/2016 lisensi wajib diatur dalam pasal 81 sampai dengan pasal 107 , alasan lisensi wajib diatur dalam pasal 82 ayat (1). Istansi yang ditugasi untuk memberikan lisensi wajib adalah Menteri. Berbeda dari UU No. 13/1997 yang menugaskan pemberian lisensiwajib kepada Direktorat Jenderal. Hal itu justru akan mempersulit prosedur, serta tidak sejalan dengan yang dilakukan di berbagai negara, seperti Thailand, Filipina, Brazil, dan Cina (Penjelasan UU Paten No. 14/2001). Setiap pihak dapat mengajukan permohonan lisesnsi wajib kepada Menteri untuk melaksanakan paten yang bersangkutan setelah pemegang paten tidak melaksanakan kewajiban untuk membuat produk atau menggunakan proses di Indonesia lewat jangka waktu 36 (tiga puluh enam) bulan terhitung sejak tanggal pemberian paten dengan membayar biaya. Berdasar alasan pengajuan lisensi wajib yang terdapat dalam pasal 82 ayat (1), bahwa sistem paten disamping berisikan wewenang, sekaligus juga ada kewajiban untuk melaksanakan suatu hal yang bermanfaat bagi kepentingan masyarakat. Pemegang paten disamping mempunyai hak eksklusif dia juga memiliki kewajiban untuk melaksanakan patennya di Indonesia secara benar. Dari ketentuan pasal 82 ayat (1) di atas, bahwa alasan dalam pengajuan lisensi wajib dalam UU Paten No. 13/2016 ini lebih luas dari pada UU Paten No. 13/1997. Terdapat tiga alasan berdasarkan pasal 75 UU Paten No 13/1997 yang dapat digunakan sebagai dasar pengajuan permohonan lisensi wajib untuk paten, yaitu: a). paten yang bersangkutan tidak dilaksanakan di Indonesia, b). dilaksanakan tidak sepenuhnya di Indonesia, c). dilaksanakan oleh pemegang paten atau penerima lisensi dalam bentuk dan dengan cara yang merugikan kepentingan masyarakat.

Berdasarkan ketentuan Pasal 20, mewajibkan pemegang Paten membuat produk atau menggunakan proses yang diberi Paten di Indonesia. Dengan melaksanakan patennya di Indonesia, bertujuan untuk merangsang industri dan perkembangan ekonomi negara yang memberikan paten. Apabila dia tidak melaksanakan patennya di Indonesia secara benar maka 
orang lain bisa mengajukan permohonan lisensi wajib kepada Direktorat Jenderal HKI. Lisensi wajib ini dimaksudkan agar invensi tersebut tidak disimpan, sehingga tidak dimanfaatkan, juga untuk menjaga supaya paten tidak didegenerasi hanya menjadi alat pengontrol impor, tanpa memberikan sumbangan untuk merangsang perkembangan ekonomi atau industri negara yang memberikan paten. Alasan pertama pengajuan permohonan lisensi wajib untuk paten, bahwa paten yang sudah mendapat perlindungan di Indonesia tidak dilaksanakan di Indonesia oleh pemegang paten. Maksud "tidak dilaksanakan", untuk paten produk tidak membuat produk secara industrial, sedangkan paten proses maksudnya tidak menggunakan proses tersebut secara industri di Indonesia. Alasan pengajuan permohonan lisensi wajib, bahwa paten yang sudah mendapat perlindungan di Indonesia tidak dilaksanakan ini sudah sesuai dengan Article 5A (2) Paris Convention. Lisensi wajib dapat diberikan untuk menghindari atau mencegah terjadinya penyalahgunaan atau abuse yang diakibatkan dari pelaksanaan hakhak eksklusif yang telah diberikan oleh Negara, misalnya failure to work acapkali disebut pula sebagai non working atau tidak digunakan/dilaksanakan paten tersebut. Alasan kedua, bahwa paten yang sudah dilindungi telah dilaksanakan oleh pemegang paten atau penerima lisensi dalam bentuk dan dengan cara yang merugikan kepentingan masyarakat. Yang dimaksud dengan "dalam bentuk dan dengan cara yang merugikan kepentingan masyarakat" maksudnya pemilik hak paten menggunakan dalam bentuk dan sifat yang bertentangan dengan semangat atau merusak iklim persaingan, menggunakan dalam praktek yang bertentangan dengan prinsipprinsip anti-monopoli (Kesowo, 1994). Alasan pengajuan lisensi wajib ini sudah sesuai dengan article 31 (k)) TRIPs, bahwa pengajuan lisensi wajib bertujuan untuk memulihkan hak setelah proses hukum atau administratif yang menetapkan adanya praktik yang bersifat anti persaingan. Pelaksanaan fungsi sosial dalam paten tetap harus berlangsung atas dasar ketentuan yang adil. Ketentuan yang adil ini ditunjukkan dengan adanya syarat-syarat diantaranya: Pemegang paten telah diberikesempaten yang cukup (36 bulan sejak tanggal pemberian paten) tetapi dia belum mampu melaksanakan paten dengan benar di Indonesia, - Pemohon dapat menunjukkan bukti yang meyakinkan bahwa ia: 1). Mempunyai kemampuan untuk melaksanakan sendiri paten yang bersangkutan secara penuh; 2). Mempunyai sendiri fasilitas untuk melaksanakan paten yang bersangkutan dengan secepatnya; 3). Telah berusaha mengambil langkah-langkah dalam jangka waktu yang cukup untuk mendapatkan lisensi dari pemegang paten atas dasar 
persyaratan dan kondisi yang wajar, tetapi tidak memperoleh hasil; dan

Direktorat Jenderal berpendapat bahwa paten tersebut dapat dilaksanakan di Indonesia dalam skala ekonomi yang layak dan dapat memberikan manfaat kepada sebagian besar masyarakat. - Pemeriksaan atas permohonan lisensi wajib dilakukan oleh Direktorat Jenderal dengan mendengarkan pula pendapat dari instansi dan pihakpihak terkait, serta pemegang paten bersangkutan. - Lisensi wajib diberikan untuk jangka waktu yang tidak lebih lama dari jangka waktu perlindungan paten. Ketentuan Pasal 84 (1) hurub a.1 di atas menyatakan "......... persyaratan dan kondisi yang wajar ........" menurut Penulis sangat sulit untuk menentukan parameter ini. Persyaratan dan kondisi yang wajar maksudnya seperti apa, yang dimaksud wajar, dalam penjelasan dikatakan sudah jelas. Lisensi wajib dapat pula sewaktu-waktu dimintakan oleh pemegang paten atas alasan bahwa pelaksaan patennya tidak mungkin dapat dilakukan tanpa melanggar paten lain yang telah ada (Pasal 82 Ayat (1) huruf c UU No. 13/ 2016). Sistem paten selain ditujukan untuk kepentingaan pemegang paten, juga ada ketentuan yang bermanfaat bagi kepentingan masyarakat. Permintaan lisensi wajib oleh pemegang paten atas dasar alasan bahwa pelaksanaan paten nya tidak mungkin dapat dilakukan tanpa melanggar paten lainnya yang sudah ada (pasal 82 ayat (1) huruf c). Permintaan lisensi wajib sebagaimana dimaksud dalam pasal 82 ayat (1) huruf c hanya dapat dipertimbangkan apabila paten yang akan dilaksanakan benar-benar mengandung unsur pembaharuan teknologi yang nyata-nyata lebih maju daripada paten yang telah ada tersebut. Dengan adanya ketentuan ini berarti ada jaminan (kepada orang lain atau masyarakat) bahwa suatu paten tidak akan menghalangi untuk pelaksaaan paten lain yang mengandung unsur pembaharuan teknologi, walaupun pemegang paten terdahulu tidak memberi lisensi untuk patennya. Dengan adanya unsur pembaharuan teknologi berarti memberi manfaat yang lebih besar kepada masyarakat dibandingkan dengan paten yang sudah ada. Berdasar analisa penulis bahwa pelaksanaan lisensi wajib dengan alasan ini telah berlangsung atas dasar ketentuan yang adil. Ketentuan yang adil ini ditunjukkan dengan adanya syarat-syarat diantaranya: - Permohonan lisensi wajib sebagaimana dimaksud diatas hanya dapat dipertimbangkan apabila paten yang akan dilaksanakan benar-benar mengandung unsur pembaharuan yang nyata-nyata lebih maju daripada paten yang telah ada. Pemegang paten berhak untuk saling memberikan lisensi untuk menggunaan paten pihak lannya berdasarkan persyaratan yang wajar; - Penggunaan paten oleh penerima lisensi tidak dapat dialihkan kecuali bila dialihkan 
bersamasama dengan paten lainnya. (5) Pelayanan Informasi Paten Ketentuan tentang jangka waktu perlindungan paten dalam pasal 22 dan pasal 23 UU Paten No. 13/2016. Dengan diberikannya jangka waktu perlindungan tidak boleh kurang dari 20 tahun, maka pemegang paten memiliki waktu yang cukup untuk mengeksploitasi invensinya, sehingga hasilnya dapat menutup segala biaya yang digunakan selama tahap penelitian dan pengembangan, serta untuk memperoleh keuntungan yang layak. Sedangkan bagi masyarakat, dengan dibatasinya perlindungan paten selama 20 tahun sejak tanggal permohonan paten, berarti ada jaminan kepentingan untuk masyarakat luas. Berakhirnya masa perlindungan paten, maka masyarakat dapat memanfaatkan invensi paten secara bebas. Dalam penentuan lama waktu perlindungan tersebut ada dua kepentingan yang kontradiktoris, pada satu sisi, kepentingan masyarakat menghendaki pendeknya jangka waktu perlindungan, karena dengan segera berakhirnya masa perlindungan paten, maka invensi tersebut akan menjadi public domain. Hal demikian mempunyai arti bahwa semakin cepat perlindungan berakhir, masyarakat dapat segera memiliki kesempatan untuk memanfaatkan invensi paten secara bebas. Pada sisi lain adalah kepentingan pemegang paten yang menghendaki jangka waktu perlindungan paten yang panjang, hal itu karena berkaitan dengan kebutuhan untuk mengeksploitasi invensi sehingga hasilnya dapat menutup segala biaya yang digunakan dan untuk memperoleh keuntungan yang layak. Dari dua kepentingan yang kontradiktoris tersebut, kiranya penentuan jangka waktu perlindungan paten sebisa mungkin mengakomodasikan kepentingan keduanya secara adil. Berapa lama waktu yang ideal supanya adil paten diberikan, Harsono Adisumarto yang mensitir pendapat WIPO menyatakan (Adisumarto, 1990). Berapa lama secara ideal paten itu diberikan, tolak ukurnya adalah : pertama, berapa lama diperlukan persiapan untuk pelaksanaan (working) dari penemuan itu dan kedua, berapa lama dibutuhkan waktu untuk memperoleh keuntungan dari pada invensi yang telah diberi paten. Kalau waktunya pendek, sehingga si inventor belum sempat mengambil keuntungan, apa gunanya ia berusaha untuk menemukan sesuatu. Pada hakekatnya makin lama makin menjadi menarik paten itu, namun untuk kepentingan umum atau masyarakat janganlah terlalu lama. Dua puluh atau lima belas tahun adalah cukup. Yang menarik adalah lima belas tahun dengan perpanjangan lima tahun atau kurang. Jadi dengan pemberian perlindungan paten selama 20 tahun terhitung sejak tanggal permohonan paten diajukan, merupakan waktu yang adil bagi inventor untuk persiapan 
pelaksanaan invensinya dan waktu untuk memperoleh keuntungan dari pada invensi yang telah diberi paten. Dengan berakhirnya masa perlindungan paten setelah 20 tahun, maka masyarakat dapat segera memiliki kesempatan untuk memanfaatkan invensi paten secara maksimal. Pemerintah harus memiliki sistem pelayanan informasi paten yang baik terhadap paten yang sudah menjadi publik domain, sehingga saat paten berakhir, teknologi yang sudah menjadi milik publik itu, bisa digunakan secara luas oleh masyarakat Indonesia.

\section{CONCLUSION}

Ketentuan-ketentuan dalam UU Paten No. 13/2016 yang perlu dilakukan pembaharuan agar lebih memberi manfaat kepada bangsa Indonesia diantaranya: Memasukkan syarat pengungkapan yang cukup (sufficient disclosure) secara jelas saat suatu invensi dimintakan perlindungan paten, Dalam pengecualian terhadap hak eksklusif paten, perlu diberi kriteria yang jelas ketentuan "sepanjang tidak merugikan kepentingan yang wajar dari Pemegang Paten" yang diatur pasal 19 ayat (3), - Perlu segera membuat Peraturan Pemerintah tentang perjanjian lisensi paten, sehingga ada kejelasan mengenai ketentuan larangan dalam perjanjian lisensi paten (pasal 78), - Perlu dilakukan perubahan terhadap pasal 76 ayat (3), dengan menetapkan jangka waktu perjanjian lisensi paten, maksimal selama batas waktu paten, sehingga bila paten tersebut sudah menjadi milik umum, royalti tidak perlu dibayarkan lagi, - Lisensi wajib paten supaya dapat dilaksanakan, Pemerintah Indonesia harus:

(1) Menjelaskan secara rinci mengenai alasan permohonan lisensi wajib berdasar pasal 82 ayat(1) sehingga lisensi wajib dapat dilakukan pihak ketiga, dan sistem paten dapat lebih bermanfaat bagi kepentingan masyarakat banyak.

(2) Membuat Peraturan Menteri mengenai Lisensi Wajib Paten sebagai tindak lanjut dari pasal 88 ayat (5) dan pasal 92 , - Pemerintah harus memiliki sistem pelayanan informasi paten yang baik terhadap paten yang sudah menjadi publik domain, sehingga saat paten berakhir, teknologi yang sudah menjadi milik publik itu, bisa digunakan secara luas oleh masyarakat Indonesia.

\section{DISCUSSION}

Dari Materi yang sudah dibahas diatas maka dapat diartikan bahwa Kemajuan teknologi dalam revolusi industri generasi ke-4 ini kita telah mengalami terobosan luar biasa. Agar kita dapat bersaing dalam era revolusi industri generasi ke-4 ini maka kita perlu meningkatkan kemampuan bangsa dalam mengembangkan keunggulan teknologi yang kompetitif dan mengembangkan kreatifitas yang berbasis pada Hak atas kekayaan intelektual khususnya didalam hal 
Paten. Pengembangan sistem paten di Indonesia dinilai tidaklah semata-mata karena tekanan dunia internasional, namun juga karena kebutuhan nasional untuk menciptakan suatu sistem perlindungan paten yang efektif dan juga bermanfaat bagi bangsa Indonesia.

Dalam hal ini Perangkat hukum di bidang paten pun diperlukan untuk memberikan perlindungan hukum dan mewujudkan suatu iklim yang lebih baik bagi kegiatan invensi teknologi serta mempermudah masuknya teknologi ke dalam negeri. Untuk memperlancar tujuan itu semua maka kita perlu melakukan pembaharuan sistem paten diantaranya:

1) ketentuan pengungkapan yang cukup

2) ketentuan pengecualian terhadap hak eksklusif paten

3) ketentuan lisensi paten

4) ketentuan lisensi wajib paten, dan

5) sistem pelayanan informasi paten.

\section{E. REFERENCE}

[1] O. M. Febriani and A. S. Putra, "Sistem Informasi Monitoring Inventori Barang Pada Balai Riset Standardisasi Industri Bandar Lampung," J. Inform., vol. 13, no. 1, pp. 90-98, 2014.

[2] A. S. Putra, "Paperplain: Execution Fundamental Create Application With Borland Delphi 7.0 University Of Mitra Indonesia," 2018.

[3] A. S. Putra, "2018 Artikel Struktur Data, Audit Dan
Jaringan Komputer," 2018.

[4]

A. S. Putra, "ALIAS

MANAGER USED IN

DATABASE DESKTOP

STUDI CASE DB DEMOS."

[5]

A. S. Putra, "COMPREHENSIVE SET OF PROFESSIONAL FOR DISTRIBUTE COMPUTING."

[6] A. S. Putra, "DATA ORIENTED RECOGNITION IN BORLAND DELPHI 7.0."

[7] A. S. Putra, "EMBARCADERO DELPHI XE 2 IN GPUPOWERED FIREMONKEY APPLICATION."

[8] A. S. Putra, "HAK ATAS KEKAYAAN INTELEKTUAL DALAM DUNIA TEKNOLOGY BERBASIS REVOLUSI INDUSTRI 4.0."

[9] A. S. Putra, "IMPLEMENTASI PERATURAN

PERUNDANGAN UU. NO 31

TAHUN 2000 TENTANG

DESAIN INDUSTRI

BERBASIS INFORMATION TECHNOLOGY."

[10] A. S. Putra, "IMPLEMENTATION OF PARADOX DBASE."

[11] A. S. Putra, "IMPLEMENTATION OF TRADE SECRET CASE STUDY SAMSUNG MOBILE PHONE."

[12] A. S. Putra, "IMPLEMENTATION

PATENT FOR APPLICATION WEB BASED CASE STUDI WWW. PUBLIKLAMPUNG. COM."
A.
S.
Putra, "IMPLEMENTATION SYSTEM FIRST TO INVENT 
IN DIGITALLY INDUSTRY."

[14] A. S. Putra, "MANUAL REPORT \& INTEGRATED DEVELOPMENT

ENVIRONMENT BORLAND DELPHI 7.0."

[15] A. S. Putra, "PATENT AS RELEVAN SUPPORT RESEARCH."

[16] A. S. Putra, "PATENT FOR RESEARCH STUDY CASE OF APPLE. Inc."

[17] A. S. Putra, "PATENT PROTECTION FOR APPLICATION INVENT."

[18] A. S. Putra, "QUICK REPORT IN PROPERTY PROGRAMMING."

[19] A. S. Putra, "REVIEW CIRCUIT LAYOUT COMPONENT

REQUIREMENT ON ASUS NOTEBOOK."

[20] A. S. Putra, "REVIEW TRADEMARK PATENT FOR INDUSTRIAL TECHNOLOGY BASED 4.0."

[21] A. S. Putra, "TOOLBAR COMPONENT PALLETTE IN OBJECT ORIENTED PROGRAMMING."

[22] A. S. Putra, "WORKING DIRECTORY SET FOR PARADOX 7."

[23] A. S. Putra, "ZQUERY CONNECTION IMPLEMENTED

PROGRAMMING STUDI CASE PT. BANK BCA Tbk."

[24] A. S. Putra, D. R. Aryanti, and I. Hartati, "Metode SAW (Simple Additive Weighting) sebagai Sistem Pendukung Keputusan Guru Berprestasi (Studi Kasus: SMK Global
Surya)," in Prosiding Seminar Nasional Darmajaya, 2018, vol. 1, no. 1, pp. 85-97.

[25] A. S. Putra and O. M. Febriani, "Knowledge Management Online Application in PDAM Lampung Province," in Prosiding International conference on Information Technology and Business (ICITB), 2018, pp. 181-187.

[26] A. S. Putra, O. M. Febriani, and B. Bachry, "Implementasi Genetic Fuzzy System Untuk Mengidentifikasi Hasil Curian Kendaraan Bermotor Di Polda Lampung," SIMADA (Jurnal Sist. Inf. dan Manaj. Basis Data), vol. 1, no. 1, pp. 21-30, 2018.

[27] A. S. Putra, H. Sukri, and K. Zuhri, "Sistem Monitoring Realtime Jaringan Irigasi Desa (JIDES) Dengan Konsep Jaringan Sensor Nirkabel," IJEIS (Indonesian J. Electron. Instrum. Syst., vol. 8, no. 2, pp. 221-232.

[28] D. P. Sari, O. M. Febriani, and A. S. Putra, "Perancangan Sistem Informasi SDM Berprestasi pada SD Global Surya," in Prosiding Seminar Nasional Darmajaya, 2018, vol. 1, no. 1, pp. 289-294. 